Check for updates

Cite this: RSC Adv., 2018, 8, 8805

Received 18th October 2017 Accepted 7th February 2018

DOI: 10.1039/c7ra11495h

rsc.li/rsc-advances

\section{Dual role of coal fly ash in copper ion adsorption followed by thermal stabilization in a spinel solid solution $\uparrow$}

\begin{abstract}
Pengfei Wu, ${ }^{\text {ab }}$ Yuanyuan Tang (D)*ac and Zongwei Cai (D) ${ }^{\mathrm{b}}$
Coal fly ash is usually used as a cost-effective adsorbent for heavy metal removal, accumulating large amounts of spent coal fly ash that requires further disposal. In this study, fly ash that adsorbs copper with a maximum copper adsorption capacity of $48.8 \mathrm{mg} \mathrm{g}^{-1}$ was further sintered at $900-1050{ }^{\circ} \mathrm{C}$, and it was found that the copper is thermally incorporated in a spinel structure in aluminum- and iron-containing ceramic matrices provided by the fly ash. To further explore the immobilization mechanisms of copper in both aluminum- and iron-containing ceramic matrices like those in fly ash, two systems were prepared from $\mathrm{CuO}+\mathrm{Fe}_{2} \mathrm{O}_{3}+$ kaolinite and $\mathrm{CuO}+\mathrm{Fe}_{2} \mathrm{O}_{3}+\mathrm{Al}_{2} \mathrm{O}_{3} \cdot \mathrm{A} \mathrm{CuAl}_{x} \mathrm{Fe}_{2-x} \mathrm{O}_{4}$ spinel solid solution was formed, the peak intensity of which was found to increase upon an increase in the sintering temperature until a maximum amount was reached at $1150{ }^{\circ} \mathrm{C}$. In the $\mathrm{CuO}+\mathrm{Fe}_{2} \mathrm{O}_{3}+\mathrm{Al}_{2} \mathrm{O}_{3}$ system, the $2 \theta$ value of the $\mathrm{CuAl}_{x} \mathrm{Fe}_{2-x} \mathrm{O}_{4}$ peaks was found to increase due to the continuous engagement of aluminum in the spinel structure. However, iron was found to be more likely to react with the copper in $\mathrm{CuO}+\mathrm{Fe}_{2} \mathrm{O}_{3}+$ kaolinite during the formation of $\mathrm{CuAl}_{x} \mathrm{Fe}_{2-x} \mathrm{O}_{4}$. Through effective adsorption of copper on coal fly ash and the subsequent copper stabilization in the spinel, this study found a dual role for fly ash in copper immobilization and further confirmed the potential to recycle waste coal fly ash as a marketable ceramic material.
\end{abstract}

\section{Introduction}

Heavy metal contamination has always been a significant environmental concern by virtue of anthropogenic activities and industrialization in many areas. ${ }^{1,2}$ Copper ions, once they enter organisms, accumulate, and the bioaccumulation leads to various diseases and disorders. ${ }^{3,4}$ It has been found that living in an environment with excessive copper can increase the risk of diseases such as lung cancer, ${ }^{\mathbf{5}}$ hepatolenticular degeneration, ${ }^{6}$ and Alzheimer's disease. ${ }^{7}$ Nowadays, a variety of technologies have been applied to remove copper ions through electrolysis, ${ }^{8}$ membrane separation, ${ }^{9}$ ionic exchange process, ${ }^{10}$ chemical precipitation, ${ }^{\mathbf{1 1}}$ etc. However, the aforementioned technologies are usually limited by economic feasibility, technical difficulties, and/or recovery rate. ${ }^{\mathbf{1 2 - 1 4}}$ With the accessibility of inexpensive and efficient adsorbents, adsorption has been widely

${ }^{a}$ School of Environmental Science and Engineering, Southern University of Science and Technology, 1088 Xueyuan Blvd, Nanshan District, Shenzhen 518055, P. R. China. E-mail: tangyy@sustc.edu.cn; Tel: +86-755-88015460

${ }^{b}$ State Key Laboratory of Environmental and Biological Analysis, Department of Chemistry, Hong Kong Baptist University, Hong Kong SAR, P. R. China

${ }^{c}$ Key Laboratory of Municipal Solid Waste Recycling Technology and Management of Shenzhen City, Shenzhen 518055, P. R. China

$\dagger$ Electronic supplementary information (ESI) available: Supporting information is available free of charge and includes 8 pages containing 2 equations, 5 tables and 1 figure. See DOI: 10.1039/c7ra11495h used as the simplest and most available technology to remove copper ions from aqueous solutions. ${ }^{15,16}$

Fly ash is mainly generated from pulverized coal combustion processes as an inevitable by-product ${ }^{17,18}$ and has gained popularity as a significant adsorbent for the removal of a variety of organic compounds and heavy metals. ${ }^{19-21}$ The annual amount of coal fly ash produced has been reported to be approximately 750 million tons worldwide, ${ }^{22,23}$ and more up-todate statistics show that the annual generation of fly ash in China alone is anticipated to be more than 600 million tons. ${ }^{24}$ Without proper treatment, such a huge amount of fly ash can disrupt ecological cycles and pose potential environmental hazards. ${ }^{25}$ Moreover, the costs for fly ash management are significant and are continuously increasing due to more stringent regulations. ${ }^{26}$ Fly ash is usually composed of particles with a porous structure and sizes ranging from 0.5 to $300 \mu \mathrm{m},{ }^{21}$ which provide possible sites to accommodate large quantities of cations. Therefore, because it is a low-cost and effective adsorbent, numerous studies have reported that there are remarkable economic and environmental benefits to reutilizing fly ash. ${ }^{21,22}$

Even after being adsorbed on fly ash, copper ions are likely to be released from the copper-adsorbed fly ash, thus regenerating the adsorbent. Although the regeneration of metal-loaded fly ash has been achieved by desorbing the contaminants, ${ }^{27,28}$ the adsorption capacity of the fly ash was found to always significantly decrease after repeated cycles of desorption, ${ }^{\mathbf{2 9 , 3 0}}$ leading 
to the accumulation of waste metal-laden fly ash. It has been reported that heavy metals adsorbed on adsorbents may leach from the adsorbents when they are placed in the environment. ${ }^{31,32}$ For example, Mori et $a .^{33}$ reported that more than $15 \%$ of copper ions in copper-adsorbed mortars could be easily eluted using a solution of $\mathrm{CH}_{3} \mathrm{COONa}-\mathrm{CH}_{3} \mathrm{COOH}$. Therefore, a reliable and applicable approach is urgently needed to prevent the consequential environmental pollution caused by the continuous generation of waste metal-laden fly ash. It has been reported that hazardous metal-containing wastes can be used to fabricate ceramic products, ${ }^{34,35}$ with the hazardous metals being effectively stabilized in matrices rich in aluminum (Al), silicon (Si), and iron (Fe) via encapsulation into a variety of crystal structures. ${ }^{36,37}$ Aluminum, silicon, and iron have also been reported as predominant components in coal fly ash, ${ }^{38,39}$ which provides a possible matrix for heavy metal stabilization after its exhaustion as a heavy metal adsorbent. Therefore, in this work, coal fly ash is used as an adsorbent for copper removal from aqueous solutions, and its dual role in the immobilization of heavy metals is further studied.

In copper-containing systems either rich in aluminum or iron, crystalline phases with a spinel structure can be generated with the chemical formulae $\mathrm{CuAl}_{2} \mathrm{O}_{4}$ and $\mathrm{CuFe}_{2} \mathrm{O}_{4}$, respectively. ${ }^{36,37}$ However, in fly ash containing both aluminum and iron as the major components, a different mechanism is anticipated due to the competition for copper between aluminum and iron during thermal processes. This study will first investigate the adsorption of copper ions on coal fly ash, and then propose a ceramic sintering scheme for the disposal of the copper-adsorbed fly ash. Furthermore, to extensively study the mechanisms of copper incorporation and competition by aluminum and iron, two simulated copper-laden systems were prepared from mixtures of hematite $\left(\mathrm{Fe}_{2} \mathrm{O}_{3}\right)$ with kaolinite and $\gamma-\mathrm{Al}_{2} \mathrm{O}_{3}$, respectively. Through the successful immobilization of copper ions during the ceramic sintering processes, the waste metal-adsorbed fly ash can be further beneficially used to fabricate a variety of ceramic products. With this dual effect of fly ash on copper removal from waste streams and further stabilization for marketable ceramic products, this study suggests an effective and economical way to relieve the environmental burden caused by metal-laden waste and proposes a "waste-to-resource" strategy to achieve the sustainable management of solid wastes.

\section{Experimental}

\subsection{Copper ion adsorption}

Adsorption isotherm experiments were conducted to evaluate the adsorption capacity of coal fly ash (Fig. S1 of the ESI $\dagger$ ) for different concentrations of copper ions using $\mathrm{Cu}\left(\mathrm{NO}_{3}\right)_{2}$ (Aladdin Chemistry Co., Shanghai). The fly ash was collected from Castle Peak Power Station, the largest coal-fired power station in Hong Kong. The elemental compositions of the fly ash were determined using X-ray fluorescence (XRF) (JSX-3201Z, JEOL, Tokyo, Japan) and normalized by their oxide forms (Table $\mathrm{S} 1$ of the ESI $\dagger$ ). From the results, the fly ash was classified as Class F by The American Society for Testing and Materials
(ASTMs), with a combined $\mathrm{SiO}_{2}, \mathrm{Al}_{2} \mathrm{O}_{3}$, and $\mathrm{Fe}_{2} \mathrm{O}_{3}$ content of greater than $70 \%$. The particle size distribution of the collected fly ash was measured using a laser scattering technique (Mastersizer 3000, Malvern), and the values $D_{\mathrm{v}}(10), D_{\mathrm{v}}(50), D_{\mathrm{v}}(90)$ as $37.5 \mu \mathrm{m}, 62.2 \mu \mathrm{m}, 91.1 \mu \mathrm{m}$ were found. Batch experiments were performed in a $50 \mathrm{~mL}$ clear plastic bottle with $20 \mathrm{mg}$ of adsorbent and $20 \mathrm{~mL}$ of aqueous solution at a pH of around 7.11 at room temperature. Copper containing solutions were prepared with a variety of copper concentrations ranging from 20 to $160 \mathrm{mg} \mathrm{L}{ }^{-1}$. The initial $\mathrm{pH}$ values of all of the solutions were adjusted to $\sim 5.3$ by adding negligible volumes $(<0.2 \mathrm{~mL})$ of $0.1 \mathrm{~mol} \mathrm{~L}^{-1} \mathrm{NaOH}$ or $\mathrm{HCl} .20 \mathrm{mg}$ of coal fly ash was then added into each solution for copper adsorption. After stirring at a shaking speed of $180 \mathrm{rpm}$ for $20 \mathrm{~h}$, the fly ash was then separated from the solution using a membrane filter $(0.45 \mu \mathrm{m})$. The $\mathrm{pH}$ of the final solution was measured and was found to be stable at 7.1. Both residues and filtered solutions were stored at $4{ }^{\circ} \mathrm{C}$ for further analysis. The concentrations of the copper ions were determined using inductively coupled plasma optical emission spectrometry (ICP-OES, PerkinElmer, Optima $8000 \mathrm{DV})$. The amount of copper ions adsorbed per unit mass of coal fly ash was calculated using the mass balance equation as follows:

$$
q=\frac{c_{0}-c_{\mathrm{e}}}{m} v
$$

where $q$ is the amount of copper ions adsorbed per gram of fly ash ( $\left.\mathrm{mg} \mathrm{g}^{-1}\right) ; c_{0}$ and $c_{\mathrm{e}}$ are the initial and equilibrium concentrations of the copper ions in the solution $\left(\mathrm{mg} \mathrm{L}^{-1}\right) ; m$ is the mass of the coal fly ash (g); and $v$ is the volume of the copper ion-containing solution (L).

\subsection{Sample preparation for ceramic sintering}

Three sample systems were prepared for an intensive study on the copper immobilization mechanisms in the aluminum- and iron-matrices of the fly ash systems during thermal processes. Firstly, the copper-adsorbed fly ash was collected from solutions with an initial copper ion concentration of $80 \mathrm{mg} \mathrm{L}^{-1}$ and was dried at $60{ }^{\circ} \mathrm{C}$ before being used in further experiments. Secondly, to clarify the effect of iron and aluminum on copper immobilization, samples were further prepared by mixing $\mathrm{CuO}$ $+\mathrm{Fe}_{2} \mathrm{O}_{3}$ with kaolinite (Fisher Scientific) or $\gamma-\mathrm{Al}_{2} \mathrm{O}_{3}$ (sintered from AlOOH (Pural SB, Sasol) at $650{ }^{\circ} \mathrm{C}$ for $5 \mathrm{~h}$ ), respectively. Each mixture was prepared with a total sample weight of $60 \mathrm{~g}$ at a molar ratio of $\mathrm{Cu}: \mathrm{Al}: \mathrm{Fe}=1: 2: 2$ by ball milling in a water slurry for $18 \mathrm{~h}$. The slurry samples were then dried, well-ground in a mortar, and then pressed into cylindrical-shaped pellets at $650 \mathrm{MPa}$ to ensure a better solid-state reaction during the sintering processes.

All samples from the aforementioned steps were sintered in a high-temperature furnace (LHT 02/16 LB, LBR, Nabertherm Inc. Lilienthal, Germany) at temperatures ranging from 650 to $1150{ }^{\circ} \mathrm{C}$ with a heating rate of $10{ }^{\circ} \mathrm{C} \mathrm{min}^{-1}$ in air. After a dwelling time of $3 \mathrm{~h}$ at the target temperatures, each fired sample was then cooled down in the furnace to room temperature with a controlled cooling rate of $10{ }^{\circ} \mathrm{C} \mathrm{min}^{-1}$ and then well-ground into fine powders for X-ray diffraction (XRD) 
analysis. The microstructures of the sintered samples from the $\mathrm{CuO}+\mathrm{Fe}_{2} \mathrm{O}_{3}+$ kaolinite and $\mathrm{CuO}+\mathrm{Fe}_{2} \mathrm{O}_{3}+\gamma-\mathrm{Al}_{2} \mathrm{O}_{3}$ systems were further observed using a scanning electron microscope (SEM). Prior to SEM, the surfaces of the pellets were polished using a polish-grinding machine (MetaServ250, Buehler) and were gold-coated to mitigate electron charge effects.

\subsection{Sample characterization}

$\mathrm{XRD}$ is a rapid analytical technique and has been successfully used to provide accurate information about the crystal structure of materials for many decades. ${ }^{42}$ In this study, the XRD patterns of the samples were collected using a Bruker D8 Advance diffractometer (Mannheim, Germany) equipped with a LynxEye detector and a $\mathrm{CuK} \alpha_{1,2} \mathrm{X}$-ray radiation source $(40 \mathrm{kV}, 40 \mathrm{~mA})$. The $2 \theta$ scanning range was 10 to $90^{\circ}$, and the step size was $0.02^{\circ}$ with a scan speed of $0.8 \mathrm{~s}$ per step. The phase identification was executed by matching the powder XRD patterns with those retrieved from the standard powder diffraction database of the International Centre for Diffraction Data (ICDD PDF-2, Release 2008) using the JADE software (MDI Products). A SEM (Merlin SEM, ZEISS Ltd.) coupled with energy dispersive spectrometry (EDS) (ZEISS Ltd.) was employed to observe the microstructures of the $\mathrm{CuO}+\mathrm{Fe}_{2} \mathrm{O}_{3}+$ kaolinite and $\mathrm{CuO}+\mathrm{Fe}_{2} \mathrm{O}_{3}+\gamma-\mathrm{Al}_{2} \mathrm{O}_{3}$ samples that had been sintered at $950{ }^{\circ} \mathrm{C}$ for $3 \mathrm{~h}$. After surface polishing, the sample morphologies were investigated through SEM equipped with a secondary electron detector. Meanwhile, backscattered electron images were used to identify compositionally distinct areas together with multipoint-mode EDS analyses throughout this work.

\subsection{Leaching experiments}

To evaluate the effect of copper stabilization, a leaching experiment was carried out for the copper-adsorbed fly ash before and after the thermal sintering processes. The leaching experiment was modified from the U.S. EPA SW-846 Method 1311Toxicity Characteristic Leaching Procedure (TCLP), using acetic acid solution ( $\mathrm{pH}$ 2.88) as the extraction fluid. The leaching vials were filled with $10 \mathrm{~mL}$ of the leaching fluid and $0.5 \mathrm{~g}$ of the powder sample, and then rotated end-over-end at $60 \mathrm{rpm}$ for $18 \mathrm{~h}$. At the end of the agitation period, the leachates were filtered using $0.45 \mu \mathrm{m}$ syringe filters. The copper concentrations of the leachates were measured using ICP-OES. The leaching experiment was conducted in triplicate.

\section{Results and discussion}

\subsection{Copper adsorption on coal fly ash}

Fig. 1 shows the copper ion adsorption capacity of fly ash in solutions with initial copper ion concentrations ranging from 20 to $160 \mathrm{mg} \mathrm{L}^{-1}$. From Fig. 1, the copper ion adsorption capacity of fly ash rose dramatically to $49.2 \mathrm{mg} \mathrm{g}^{-1}$ when the copper ion concentration increased from 20 to $40 \mathrm{mg} \mathrm{L}^{-1}$. With a continuous increase in the copper ion concentration, the adsorption capacity of the fly ash kept slowly increasing until it reached an equilibrium at a maximum value of $58.2 \mathrm{mg} \mathrm{g}^{-1}$ in solutions with an initial copper ion concentration of higher

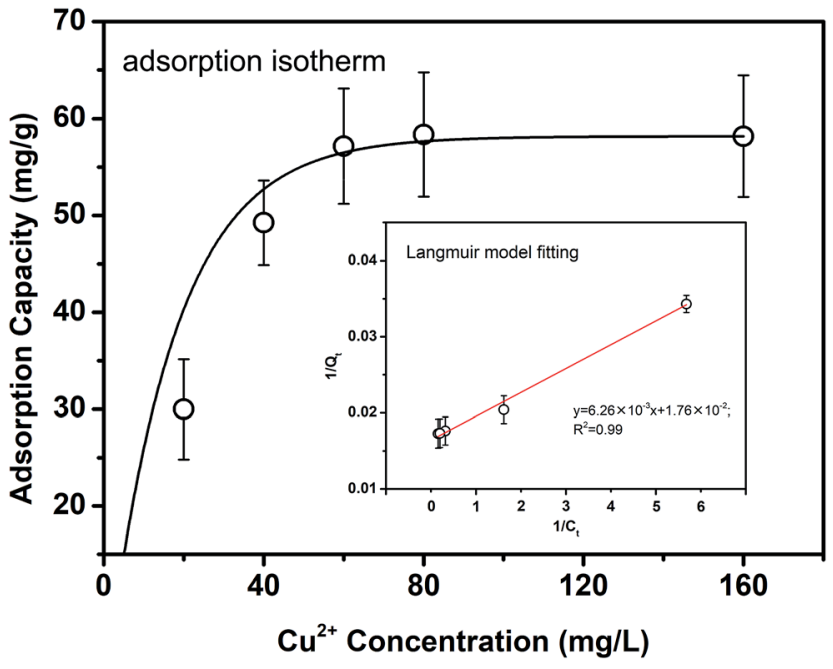

Fig. 1 Adsorption isotherm of copper ions on coal fly ash fitted using the Langmuir model and its linear expression (inset). A dramatic increase in the copper ion adsorption capacity was observed when the concentration of copper ions was increased to $40 \mathrm{mg} \mathrm{L}^{-1}$, and the maximum copper ion adsorption capacity of fly ash was found to be around $56.8 \mathrm{mg} \mathrm{g}^{-1}$.

than $60 \mathrm{mg} \mathrm{L}^{-1}$. The adsorption behavior of the copper ions on the fly ash was further analyzed by applying the linear Langmuir isotherm and Freundlich models, shown in the ESI. $\dagger$

Table 1 summarizes the parameters of both the Langmuir and Freundlich isotherm models for the adsorption of the $\mathrm{Cu}$ ions on the fly ash, along with the linear regression coefficients $\left(R^{2}\right)$. A much higher correlation coefficient was obtained from the Langmuir equation $\left(R^{2}=0.99\right)$ than that from the Freundlich equation $\left(R^{2}=0.92\right)$, which means that the adsorption results are a better fit to the Langmuir model. Since Langmuir isotherms are always involved in monolayer adsorption onto homogeneous surfaces with a finite number of identical sites, ${ }^{\mathbf{4 0 , 4 1}}$ the fitting results indicate that the interaction between the copper ions and the fly ash may be a monolayer rather than a multiple-layer adsorption process. Moreover, the theoretical maximum adsorption capacity $\left(q_{\mathrm{m}}\right)$ was calculated as $56.8 \mathrm{mg} \mathrm{g}^{-1}$ according to the Langmuir isotherm model, which is consistent with the value obtained from the adsorption experiment $\left(56.8 \mathrm{mg} \mathrm{g}^{-1}\right)$. Since the adsorption capacity is largely affected by the surface area and pore volume of the fly ash, the maximum adsorption capacity of copper ions has been reported to be approximately $100 \mathrm{mg} \mathrm{g}^{-1}$ after the modification of fly ash samples. ${ }^{42}$

\subsection{Copper immobilization in thermally treated copper- adsorbed fly ash}

Fig. 2 shows XRD patterns of the copper-adsorbed fly ash before and after thermal treatment at temperatures ranging from 900 to $1050{ }^{\circ} \mathrm{C}$. From the XRD pattern of the unsintered copperadsorbed fly ash, the main copper-hosting phase was found to be gerhardtite $\left(\mathrm{Cu}_{4}\left(\mathrm{NO}_{3}\right)_{2}(\mathrm{OH})_{6}\right.$; PDF\#77-0148). When samples were sintered at $900{ }^{\circ} \mathrm{C}$ for $3 \mathrm{~h}$, phase identification results 

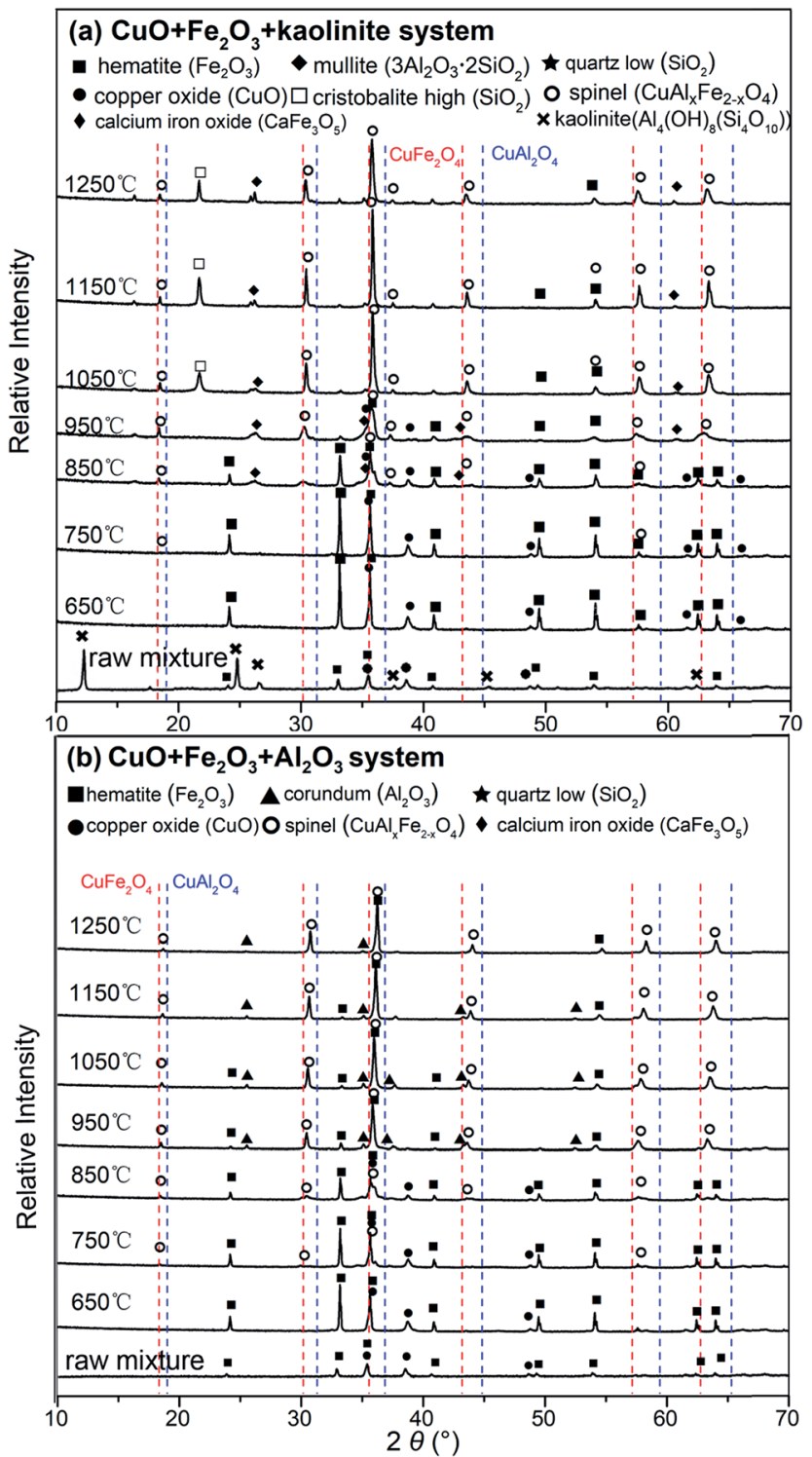

Fig. 3 XRD patterns of sintered (a) the $\mathrm{CuO}+\mathrm{Fe}_{2} \mathrm{O}_{3}+$ kaolinite system and (b) the $\mathrm{CuO}+\mathrm{Fe}_{2} \mathrm{O}_{3}+\mathrm{Al}_{2} \mathrm{O}_{3}$ system showing the thermal incorporation of copper when heated at temperatures ranging from 650 to $1250{ }^{\circ} \mathrm{C}$ for $3 \mathrm{~h}$. The crystalline phases are identified as: copper oxide (CuO; PDF\#80-0076), corundum $\left(\alpha-\mathrm{Al}_{2} \mathrm{O}_{3} ; \mathrm{PDF} \# 10-1073\right)$, hematite $\left(\mathrm{Fe}_{2} \mathrm{O}_{3}\right.$; PDF\#85-0599), spinel $\left(\mathrm{CuAl}_{x} \mathrm{Fe}_{2-x} \mathrm{O}_{4}\right)$, mullite $\left(3 \mathrm{Al}_{2} \mathrm{O}_{3} \cdot 2 \mathrm{SiO}_{2}\right.$; PDF\#79-1455), and cristobalite $\left(\mathrm{SiO}_{2}\right.$; PDF\#85-0621).

$\mathrm{Cu}$ (II) to $\mathrm{Cu}$ (I) at higher temperatures $\left(>1150{ }^{\circ} \mathrm{C}\right) \cdot{ }^{43,44}$ Fig. $3 \mathrm{~b}$ shows a similar spinel solid solution that was also generated but at a lower temperature $\left(750{ }^{\circ} \mathrm{C}\right)$ than that of the thermally sintered $\mathrm{CuO}+\mathrm{Al}_{2} \mathrm{O}_{3}+\mathrm{Fe}_{2} \mathrm{O}_{3}$ system. The spinel peaks also grew continuously with an increase in the sintering temperature, but peak shrinkage was not clearly detected at higher temperatures $\left(>1150{ }^{\circ} \mathrm{C}\right)$. Meanwhile, the signals of reactants such as $\mathrm{CuO}$, $\mathrm{Fe}_{2} \mathrm{O}_{3}$ and aluminum-containing compounds were eventually diminished with the continuous formation of the $\mathrm{CuAl}_{x} \mathrm{Fe}_{2-x} \mathrm{O}_{4}$ spinel.

Since the highest peak of the $\mathrm{CuAl}_{x} \mathrm{Fe}_{2-x} \mathrm{O}_{4}$ product phase was overlapped with those from other phases in both the $\mathrm{CuO}+$
$\mathrm{Fe}_{2} \mathrm{O}_{3}+$ kaolinite and $\mathrm{CuO}+\mathrm{Al}_{2} \mathrm{O}_{3}+\mathrm{Fe}_{2} \mathrm{O}_{3}$ systems, the second highest peak at $2 \theta$ at around $30.30^{\circ}$ was chosen for an intensive study on the reaction mechanisms during the thermal processes. Fig. 4a and b illustrate the amplification and shifting of the second largest peak of the $\mathrm{CuAl}_{x} \mathrm{Fe}_{2-x} \mathrm{O}_{4}$ generated in the $\mathrm{CuO}+\mathrm{Fe}_{2} \mathrm{O}_{3}+$ kaolinite and $\mathrm{CuO}+\mathrm{Al}_{2} \mathrm{O}_{3}+\mathrm{Fe}_{2} \mathrm{O}_{3}$ systems, respectively. As shown in Fig. 4a, the peak intensity was seen to increase dramatically when the temperature rose from 850 to $1050{ }^{\circ} \mathrm{C}$, and an obvious shifting of the peak was detected from lower to higher $2 \theta$ positions. The peak reached its maximum value at $1150{ }^{\circ} \mathrm{C}$ and decreased at a higher temperature $\left(1250{ }^{\circ} \mathrm{C}\right)$, with a slight change in the $2 \theta$ position, while in the
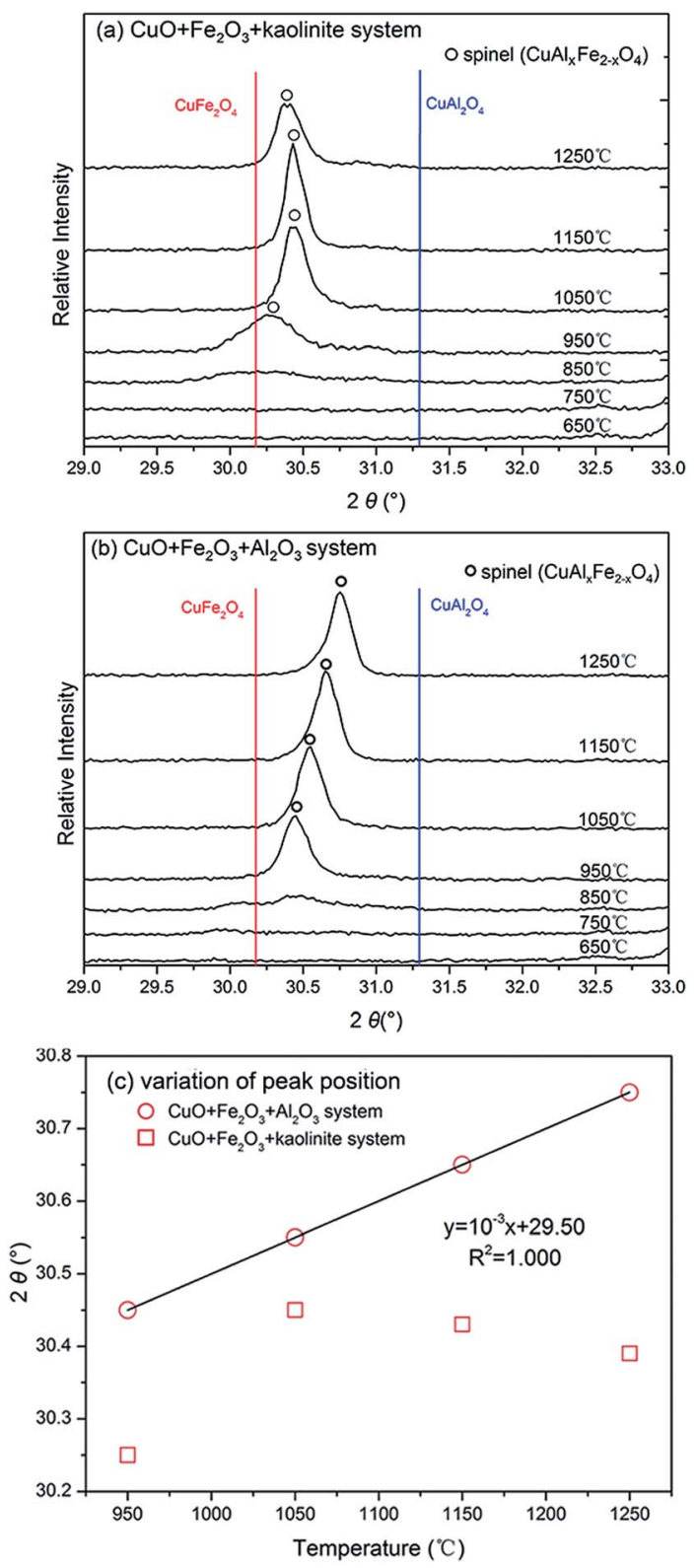

Fig. 4 Comparison of the XRD peak intensities (between $2 \theta=29.0$ and $33.0^{\circ}$ ) for (a) the $\mathrm{CuO}+\mathrm{Fe}_{2} \mathrm{O}_{3}+$ kaolinite system and (b) the $\mathrm{CuO}$ $+\mathrm{Fe}_{2} \mathrm{O}_{3}+\mathrm{Al}_{2} \mathrm{O}_{3}$ system sintered at $650-1250{ }^{\circ} \mathrm{C}$ for $3 \mathrm{~h}$, and (c) the variation of the peak positions with respect to the sintering temperature for both systems. 
$\mathrm{CuO}+\mathrm{Al}_{2} \mathrm{O}_{3}+\mathrm{Fe}_{2} \mathrm{O}_{3}$ system, the peak intensity also increased significantly when the sintering temperature rose from 850 to $950{ }^{\circ} \mathrm{C}$ but maintained a relatively steady increase afterwards with an increase in temperature until reaching a maximum value at $1150{ }^{\circ} \mathrm{C}$. Although not obviously detected, a slight decrease in the peak intensity was also found with a further $100{ }^{\circ} \mathrm{C}$ increase in the sintering temperature to $1250{ }^{\circ} \mathrm{C}$. However, unlike the variation of the peak positions for the $\mathrm{CuO}$ $+\mathrm{Fe}_{2} \mathrm{O}_{3}+$ kaolinite system, the peak positions of $\mathrm{CuAl}_{x} \mathrm{Fe}_{2-x} \mathrm{O}_{4}$ in the $\mathrm{CuO}+\mathrm{Al}_{2} \mathrm{O}_{3}+\mathrm{Fe}_{2} \mathrm{O}_{3}$ system kept steadily increasing from lower to higher $2 \theta$ values.

According to Bragg's equation, the $2 \theta$ positions of the diffraction peaks are related to the interplanar spacing $(d)$ of a crystal structure. Since the radii of aluminum atoms are smaller than those of iron atoms, the diffraction peaks of the $\mathrm{CuAl}_{2} \mathrm{O}_{4}$ spinel are located at a higher $2 \theta$ value when compared with peaks from the same lattice plane in the $\mathrm{CuFe}_{2} \mathrm{O}_{4}$ crystals. Therefore, the peak shifting of $\mathrm{CuAl}_{x} \mathrm{Fe}_{2-x} \mathrm{O}_{4}$ is due to the shrinkage of distances between lattice planes which is caused by the continuous increase in the amount of aluminum. The spinel peak shifting from a lower to a higher $2 \theta$ value indicates that is easier to engage iron ions at lower temperatures in the formation of the spinel phase, but at higher temperatures the iron ions were outcompeted by aluminum ions. Previous studies have also reported a lower sintering temperature for a ferrite spinel when compared to that of an aluminate spinel..$^{36,37}$ The tendency for peaks to shift with an increase in temperature was further analyzed and the results are shown in Fig. 4c. A perfect linear relationship was found between the $2 \theta$ value of the peak position and the sintering temperature for the $\mathrm{CuO}+\mathrm{Al}_{2} \mathrm{O}_{3}+\mathrm{Fe}_{2} \mathrm{O}_{3}$ system, which can be explained by the continuous and steady engagement of aluminum ions in the formation of the $\mathrm{CuAl}_{x^{-}}$ $\mathrm{Fe}_{2-x} \mathrm{O}_{4}$ spinel with an increase in the sintering temperature. However, the aluminum ions in $\mathrm{CuO}+\mathrm{Fe}_{2} \mathrm{O}_{3}+$ kaolinite were involved in mullite formation as reflected from the increase in the number of mullite peaks at temperatures higher than $850{ }^{\circ} \mathrm{C}$ (Fig. 3a), and therefore, there were no obvious changes observed in the $2 \theta$ positions of the $\mathrm{CuAl}_{x} \mathrm{Fe}_{2-x} \mathrm{O}_{4}$ spinel. An overall higher $2 \theta$ value for the spinel peaks was found in the $\mathrm{CuO}+\mathrm{Al}_{2} \mathrm{O}_{3}+$ $\mathrm{Fe}_{2} \mathrm{O}_{3}$ system when compared with that of the $\mathrm{CuO}+\mathrm{Fe}_{2} \mathrm{O}_{3}+$ kaolinite system, which shows a stronger competition between aluminum and iron in ceramic matrices without silicon.

\subsection{Microstructures and stabilization effect of copper- immobilized products with aluminum- and iron-rich matrices}

The microstructures of samples always play a vital role in exploring the reaction mechanisms and determining the potential applications of the products. Therefore, an investigation was further conducted on the microstructures of the $\mathrm{CuO}+$ $\mathrm{Fe}_{2} \mathrm{O}_{3}+$ kaolinite and $\mathrm{CuO}+\mathrm{Al}_{2} \mathrm{O}_{3}+\mathrm{Fe}_{2} \mathrm{O}_{3}$ systems that had been sintered at $950{ }^{\circ} \mathrm{C}$ for $3 \mathrm{~h}$ (Fig. 5). Although there is effectively a similar copper incorporation in both the $\mathrm{CuO}+$ $\mathrm{Fe}_{2} \mathrm{O}_{3}+$ kaolinite and $\mathrm{CuO}+\mathrm{Al}_{2} \mathrm{O}_{3}+\mathrm{Fe}_{2} \mathrm{O}_{3}$ systems, different
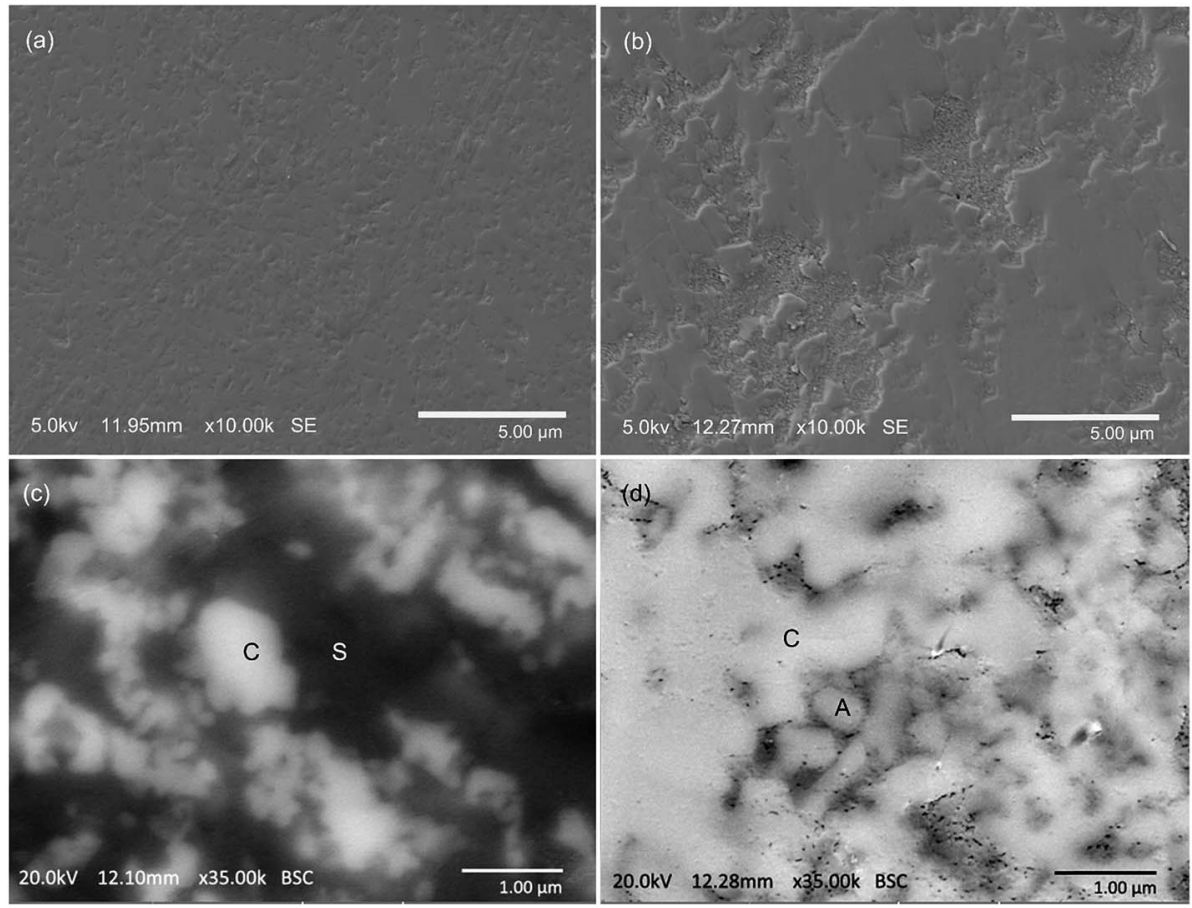

Fig. 5 Secondary electron micrographs showing (a) the highly dense microstructure sintered from the $\mathrm{CuO}+\mathrm{Fe}_{2} \mathrm{O}_{3}+\mathrm{kaolinite}$ mixture, and (b) the very porous texture of the product of $\mathrm{CuO}+\mathrm{Fe}_{2} \mathrm{O}_{3}+\mathrm{Al}_{2} \mathrm{O}_{3}$ sintered at $950{ }^{\circ} \mathrm{C}$ for $3 \mathrm{~h}$. Backscattered electron images of the polished surfaces of the products obtained from (c) the $\mathrm{CuO}+\mathrm{Fe}_{2} \mathrm{O}_{3}+$ kaolinite system and (d) the $\mathrm{CuO}+\mathrm{Fe}_{2} \mathrm{O}_{3}+\mathrm{Al}_{2} \mathrm{O}_{3}$ system sintered at $950{ }^{\circ} \mathrm{C}$ for $3 \mathrm{~h}$. The light-color grains marked ' $\mathrm{C}$ ' show an enrichment of the $\mathrm{CuAl}_{x} \mathrm{Fe}_{2-x} \mathrm{O}_{4}$ spinel solid solution, and those marked ' $\mathrm{A}$ ' are the unreacted ' $\mathrm{Al}{ }_{2} \mathrm{O}_{3}$ '. The dark-color matrix marked ' $\mathrm{S}$ ' shows the enrichment of Si. The EDS analysis is supplied in the ESI $\dagger$ to demonstrate the elemental compositions of the areas marked " $C$ ", "S", and " $A$ ". 
microstructures were detected from the secondary electron micrograph of the surface-polished samples (Fig. 5a and b). Even after being subjected to intensive surface polishing, the product of the $\mathrm{CuO}+\mathrm{Al}_{2} \mathrm{O}_{3}+\mathrm{Fe}_{2} \mathrm{O}_{3}$ system had a porous texture, whereas the crystallite grains were closely packed in the $\mathrm{CuO}+$ $\mathrm{Fe}_{2} \mathrm{O}_{3}+$ kaolinite system with a relatively smooth surface. The flux property of the silica has been reported ${ }^{36}$ to enhance mass transfer to minimize surface tension in the $\mathrm{CuO}+\mathrm{Fe}_{2} \mathrm{O}_{3}+$ kaolinite system at high temperatures, which results in a different microstructure to that of the $\mathrm{CuO}+\mathrm{Al}_{2} \mathrm{O}_{3}+\mathrm{Fe}_{2} \mathrm{O}_{3}$ system.

Backscatter electron micrographs are shown in Fig. 4c and d, which demonstrate the phase distribution in the products of the $\mathrm{CuO}+\mathrm{Fe}_{2} \mathrm{O}_{3}+$ kaolinite and $\mathrm{CuO}+\mathrm{Al}_{2} \mathrm{O}_{3}+\mathrm{Fe}_{2} \mathrm{O}_{3}$ systems. The EDS results (Tables S2-S5 in the ESI $\dagger$ ) confirmed the enrichment of silicon in the dark-colored areas marked ' $S$ ' in Fig. 4c, which might be due to the existence of mullite as clearly detected from the XRD patterns shown in Fig. 3a. The lightcolored grains marked ' $\mathrm{C}$ ' were confirmed as the formed $\mathrm{CuAl}_{x} \mathrm{Fe}_{2-x} \mathrm{O}_{4}$ spinel and were distributed separately in the flux of Si-containing materials in the $\mathrm{CuO}+\mathrm{Fe}_{2} \mathrm{O}_{3}+$ kaolinite system. However, the grains of the $\mathrm{CuAl}_{x} \mathrm{Fe}_{2-x} \mathrm{O}_{4}$ spinel (also marked with a ' $\mathrm{C}$ ') were tightly-connected to each other in the $\mathrm{CuO}+\mathrm{Al}_{2} \mathrm{O}_{3}+\mathrm{Fe}_{2} \mathrm{O}_{3}$ system. Much smaller spinel grains were found in the $\mathrm{CuO}+\mathrm{Fe}_{2} \mathrm{O}_{3}+$ kaolinite system when compared with those found in the $\mathrm{CuO}+\mathrm{Al}_{2} \mathrm{O}_{3}+\mathrm{Fe}_{2} \mathrm{O}_{3}$ system. The existence of large amounts of small-sized $\mathrm{CuAl}_{x} \mathrm{Fe}_{2-x} \mathrm{O}_{4}$ microcrystals is attributed to the homogenously distributed $\mathrm{Al}$ ions in the kaolinite structure acting as small nucleation sites for the spinel crystallization. ${ }^{36}$ In contrast, a much larger size of the $\mathrm{CuAl}_{x^{-}}$ $\mathrm{Fe}_{2-x} \mathrm{O}_{4}$ grains was observed in the $\mathrm{CuO}+\mathrm{Al}_{2} \mathrm{O}_{3}+\mathrm{Fe}_{2} \mathrm{O}_{3}$ system, which may be caused by sufficient space for the growth of crystals in the voids contained in the samples.

To evaluate the stabilization effect of copper in the sintered products, the copper concentrations of the leachates from the copper-adsorbed fly ash were measured before and after the sintering processes. The copper concentration was measured to be $1682 \mathrm{mg} \mathrm{L}^{-1}$ in the leachate from the copper-adsorbed fly ash without sintering, while that value decreased by 10 times (to $150 \mathrm{mg} \mathrm{L}^{-1}$ ) for the leachate from the $900{ }^{\circ} \mathrm{C}$ sintered sample. When the sintering temperature increased from 900 to $950{ }^{\circ} \mathrm{C}$, an obvious decrease in the copper concentration was also detected from $150 \mathrm{mg} \mathrm{L}^{-1}$ to $25.4 \mathrm{mg} \mathrm{L}^{-1}$ in the corresponding leachates. Moreover, the copper concentration was found to stabilize at around $22 \mathrm{mg} \mathrm{\textrm {L } ^ { - 1 }}$ with a further increase in the sintering temperature. Furthermore, when the copper leachability was considered with respect to the transformation of the coppercontaining phases, it was found that the copper leachability significantly reduced due to the formation of copper spinel can be seen in the XRD patterns (Fig. 2). Moreover, the results also indicated a promising temperature of $\sim 950{ }^{\circ} \mathrm{C}$ to reach satisfactory copper stabilization without extra energy consumption.

\section{Conclusions}

In this study, coal fly ash was effectively used as an adsorbent for the removal of copper ions, and the adsorption mechanism was fitted to the Langmuir model, with a maximum adsorption capacity of $48.8 \mathrm{mg} \mathrm{g}^{-1}$ based on theoretical calculations. Furthermore, to reduce the toxicity of the copper-adsorbed coal fly ash, a thermal strategy was applied to incorporate copper ions into a stable structure through interactions with aluminum and/ or iron ions in the fly ash. A spinel structure was detected in the thermally treated copper-adsorbed fly ash, and eventually grew upon an increase in the sintering temperature. The immobilization mechanisms of copper ions in both aluminum- and ironcontaining matrices were further studied using two $\mathrm{CuO}+\mathrm{Fe}_{2} \mathrm{O}_{3}$ + kaolinite and $\mathrm{CuO}+\mathrm{Al}_{2} \mathrm{O}_{3}+\mathrm{Fe}_{2} \mathrm{O}_{3}$ systems sintered from 650 to $1250{ }^{\circ} \mathrm{C}$ for $3 \mathrm{~h}$, which indicated the formation of a $\mathrm{CuAl}_{x} \mathrm{Fe}_{2-x} \mathrm{O}_{4}$ spinel solid solution. The peaks of the spinel solid solution kept growing in intensity with an increase in the temperature until a maximum value was reached at $1150{ }^{\circ} \mathrm{C}$, and decreased with any further increase in the sintering temperature. In the $\mathrm{CuO}+$ $\mathrm{Fe}_{2} \mathrm{O}_{3}+$ kaolinite system, the peaks underwent an obvious shift from lower to higher $2 \theta$ positions when the samples were heated from 850 to $1050{ }^{\circ} \mathrm{C}$ but the $2 \theta$ position changed slightly at temperatures higher than $1050{ }^{\circ} \mathrm{C}$, while in the $\mathrm{CuO}+\mathrm{Al}_{2} \mathrm{O}_{3}+$ $\mathrm{Fe}_{2} \mathrm{O}_{3}$ system, the peak position of the $\mathrm{CuAl}_{x} \mathrm{Fe}_{2-x} \mathrm{O}_{4}$ spinel kept steadily increasing from a lower to a higher $2 \theta$ value throughout the sintering scheme from 850 to $1250{ }^{\circ} \mathrm{C}$. From the observation of the product microstructures, the $\mathrm{CuO}+\mathrm{Al}_{2} \mathrm{O}_{3}+\mathrm{Fe}_{2} \mathrm{O}_{3}$ product had a porous texture, whereas the grains were closely packed in $\mathrm{CuO}+\mathrm{Fe}_{2} \mathrm{O}_{3}+$ kaolinite product, with a relatively smooth surface. Much smaller spinel grains were found in the $\mathrm{CuO}+$ $\mathrm{Fe}_{2} \mathrm{O}_{3}+$ kaolinite system when compared with those derived from the $\mathrm{CuO}+\mathrm{Al}_{2} \mathrm{O}_{3}+\mathrm{Fe}_{2} \mathrm{O}_{3}$ system. Moreover, the leaching results demonstrated that the copper leachability decreased by about 70 times when the copper-adsorbed fly ash was sintered in a temperature range of $950-1050{ }^{\circ} \mathrm{C}$. Therefore, the overall results demonstrated the dual role of coal fly ash as an adsorbent and ceramic matrix for toxic copper ion adsorption and stabilization, respectively. Through effective adsorption of copper ions on coal fly ash and the successful stabilization of toxic copper in the spinel phase thermally generated in aluminum- and ironrich ceramic matrices, the work in this study not only reduces the potential hazards caused by metal pollution but also provides a reliable "waste-to-resource" strategy for the sustainable utilization of waste coal fly ash.

\section{Conflicts of interest}

The authors declare no conflicts of interest.

\section{Acknowledgements}

This work was supported financially by the National Natural Science Foundation of China (NSFC) (21707063), Shenzhen Science and Technology Innovation Committee (JCYJ20150601155130432; JCYJ20160429191618506; ZDSYS201602261932201).

\section{References}

1 M. Guney and G. J. Zagury, Environ. Sci. Technol., 2012, 46(8), 4265-4274. 
$2 \mathrm{~K}$. Jomova and M. Valko, Advances in metal-induced oxidative stress and human disease, Toxicology, 2011, 283(2-3), 65-87.

3 R. S. Boyd, J. Chem. Ecol., 2010, 36(1), 46-58.

4 A. H. Panhwar, T. G. Kazi, H. I. Afridi, S. A. Arain, K. D. Brahaman and A. S. S. Naeemullah, Environ. Geochem. Health, 2016, 38(1), 265-274.

5 M. Ajmal, A. H. Khan, S. Ahmad and A. Ahmad, Water Res., 1988, 32(10), 3085-3091.

6 J. Świetlik, U. Raczyk-Stanislawiak, P. Piszora and J. Nawrocki, Water Res., 2012, 46(1), 1-10.

7 G. J. Brewer, Clin. Neurophysiol., 2010, 121(4), 459-460.

8 Y. Gao, Y. Zhou, H. Wang, Y. Lin, Y. Wang, D. Sun, J. Hong and Q. Li, Ind. Eng. Chem. Res., 2013, 52(17), 5871-5879.

9 W. Chen, Y. Su, J. Peng, X. Zhao, Z. Jiang, Y. Dong, Y. Zhang, Y. Liang and J. Liu, Environ. Sci. Technol., 2011, 45, 65456555.

10 J. Lv, K. Wang and T. Chung, J. Membr. Sci., 2008, 310, 557566.

11 T. A. Kurniawan, G. Y. S. Chan, W. H. Lo and S. Babel, Chem. Eng. J., 2006, 118, 83-98.

12 J. L. Huisman, G. Schouten and C. Schultz, Hydrometallurgy, 2006, 83, 106-113.

13 F. Fu and Q. Wang, J. Environ. Manage., 2011, 92, 407-418. 14 Q. Chang and G. Wang, Chem. Eng. Sci., 2007, 62, 4636-4643. 15 C. Hu, T. Zhang, Y. Huang, M. Dahab and R. Surampalli, Environ. Sci. Technol., 2005, 39(18), 7240-7245.

16 H. Wang, C. Wang, S. Tao, J. Qiu, Y. Yu and M. Gu, ACS Sustainable Chem. Eng., 2016, 4(3), 992-998.

17 Managing Coal Combustion Residues in Mines, Committee on Mine Placement of Coal Combustion Wastes, National Research Council of the National Academies (NRCNA), 2006.

18 Human and Ecological Risk Assessment of Coal Combustion Wastes, Research Triangle Park, United States Environmental Protection Agency (USEPA), 2007.

19 V. V. B. Rao and S. R. M. Rao, Chem. Eng. J., 2006, 116, 77-84.

20 C. W. Kwong and C. Y. M. Chao, Bioresour. Technol., 2010, 101, 1075-1081.

21 H. Javadian, F. Ghorbani, H. A. Tayebi and S. H. Asl, Arabian J. Chem., 2015, 8, 837-849.

22 R. S. Blissett and N. A. Rowson, Fuel, 2012, 97, 1-23.

23 M. Izquierdo and X. Querol, Int. J. Coal Geol., 2012, 94, $54-66$.

24 F. Yan, J. Jiang, S. Tian, Z. Liu, J. Shi, K. Li, X. Chen and Y. Xu, ACS Sustainable Chem. Eng., 2016, 4(9), 4654-4661.
25 M. Ilic, C. Cheeseman, C. Sollars and J. Knight, Fuel, 2003, 82, 331-336.

26 A. O. Babatunde and Y. Q. Zhao, Constructive approaches towards water treatment works sludge management: an international review of beneficial re-uses, Crit. Rev. Environ. Sci. Technol., 2007, 37(2), 129-164.

27 J. Wang, X. Teng, H. Wang and H. Ban, Environ. Sci. Technol., 2004, 38, 6710-6715.

28 J. Kuo, C. Lin and M. Y. Wey, Energy Fuels, 2008, 22(6), 37893797.

29 L. Jiang and P. Liu, ACS Sustainable Chem. Eng., 2014, 2, 1785-1794.

30 J. P. Yang, Y. C. Zhao, L. Chang, J. Y. Zhang and C. G. Zheng, Environ. Sci. Technol., 2015, 49, 8210-8218.

31 A. Deonarine, A. Kolker, A. L. Foster, M. W. Doughten, J. T. Holland and J. D. Bailoo, Environ. Sci. Technol., 2016, 50(11), 6099-6106.

32 E. Tahmasebi, M. Y. Masoomi, Y. Yamini and A. Morsali, Inorg. Chem., 2015, 54(2), 425-433.

33 M. Mori, Y. Sekine, N. Hara, K. Nakarai, Y. Suzuki, H. Kuge, Y. Kobayashi, A. Arai and H. Itabashi, Chem. Eng. J., 2013, 215-216, 202-208.

34 N. Okuno, Y. Ishikawa, A. Shimizu and M. Yoshida, Water Sci. Technol., 2004, 49(10), 225-232.

35 K. Shihand and J. O. Leckie, J. Eur. Ceram. Soc., 2007, 27, 91-99.

36 Y. Tang, S. S. Y. Chui, K. Shih and L. Zhang, Environ. Sci. Technol., 2011, 45, 3598-3604.

37 Y. Tang, K. Shih, C. Liu and C. Liao, RSC Adv., 2016, 6, 28579-28585.

38 M. Ahmaruzzaman and V. K. Gupta, Ind. Eng. Chem. Res., 2012, 51, 15299-15314.

39 T. K. Choo, Y. Song, L. Zhang, C. Selomulya and L. Zhang, Energy Fuels, 2014, 28(6), 4051-4061.

40 D. A. H. Hanaor, M. Ghadiri, W. Chrzanowski and Y. Gan, Langmuir, 2014, 30, 15143-15152.

41 K. I. Andersson, M. Eriksson and M. Norgren, Ind. Eng. Chem. Res., 2011, 50(13), 7722-7732.

42 J. Pizarro, X. Castillo, S. Jara, C. Ortiz, P. Navarro, H. Cid, H. Rioseco, D. Barros and N. Belzile, Fuel, 2015, 156, 96-102.

43 K. T. Jacob and C. B. Alcock, J. Am. Ceram. Soc., 1975, 58, 192195.

44 T. Tsuchida, R. Furuichi, T. Sukegawa, M. Furudate and T. Ishii, Thermochim. Acta, 1984, 78, 71-80. 